\title{
POKOK BAHASAN PENDIDIKAN AGAMA ISLAM DI MADRASAH: PERBANDINGAN KURIKULUM TINGKAT SATUAN (KTSP) DAN KURIKULUM 2013 (K-13)
}

\author{
Rosiddin Harahap \\ Pascasarjana Program Magister Institut Agama Islam Negeri Padangsidimpuan \\ Jalan T. Rizal Nurdin KM. 4,5 Sihitang Padangsidimpuan \\ E-mail: rosiddinhrp@yahoo.com
}

\begin{abstract}
Abstrak
Kurikulum Tingkat Satuan Pendidikan (KTSP) adalah suatu ide tentang pengembangan yang diletakkan pada posisi yang paling dekat dengan pembelajaran, yakni sekolah dan satuan pendidikan. KTSP merupakan wujud dari reformasi pendidikan yang memberikan otonomi kepada sekolah dan satuan pendidikan untuk mengembangkan kurikulum sesuai dengan potensi, tuntutan dan kebutuhan masing-masing. Sedangkan Kurikulum 2013 mempunyai tujuan untuk mendorong peserta didik atau siswa, mampu lebih baik melakukan observasi, bertanya, bernalar, dan mengkomunikasikan (mempresentasikan) apa yang mereka peroleh atau mereka ketahui setelah menerima materi pelajaran.
\end{abstract}

\begin{abstract}
Abtract
The Education Unit Level Curriculum (KTSP) is an idea of development that is placed in the position closest to learning, namely schools and educational units. KTSP is a manifestation of education reform that gives autonomy to schools and educational units to develop curriculum in accordance with their respective potentials, demands and needs. Whereas the 2013 Curriculum aims to encourage students or students to be able to better observe, ask, reason, and communicate (present) what they have acquired or know after receiving the subject matter.
\end{abstract}

Kata Kunci: Pokok Bahasan, Pendidikan, KTSP, dan K-13 


\section{Pendahuluan}

Kurikulum mempunyai peranan yang sangat signifikan dalam dunia pendidikan, bahkan bisa dikatakan bahwa kurikulum memegang kedudukan dan kunci dalam pendidikan, hal ini berkaitan dengan penentuan arah, isi, dan proses pendidikan, yang pada akhirnya menentukan macam dan kualifikasi lulusan suatu lembaga pendidikan. Kurikulum menyangkut rencana dan pelaksanaan pendidikan baik dalam lingkup kelas, sekolah, daerah, wilayah maupun nasional. ${ }^{1}$

Di Indonesia sudah beberapa kali diadakan perubahan dan perbaikan kurikulum yang tujuannya sudah tentu untuk menyesuaikannya dengan perkembangan dan kemajuan zaman, guna mencapai hasil yang maksimal. Perubahan kurikulum didasari pada kesadaran bahwa perkembangan dan perubahan yang terjadi dalam kehidupan bermasyarakat, berbangsa dan bernegara di Indonesia tidak terlepas dari pengaruh perubahan global, perkembangan ilmu pengetahuan dan teknologi, serta seni dan budaya. Perubahan secara terus menerus ini menuntut perlunya perbaikan sistem pendidikan nasional, termasuk penyempurnaan kurikulum untuk mewujudkan masyarakat yang mampu bersaing dan menyesuaikan diri dengan perubahan.

Kerangka dasar kurikulum Madrasah merupakan landasan filosofis, sosiologis, psikopedagogis dan yuridis yang berfungsi sebagai acuan pengembangan struktur kurikulum. Sedang struktur kurikulum Madrasah merupakan pengorganisasian kompetensi inti, mata pelajaran, beban belajar dan kompetensi dasar pada setiap Madrasah.

Menurut Undang-Undang RI Nomor 20 Tahun 2003 tentang Sistem Pendidikan Nasional, bahwa pendidikan nasional berfungsi mengembangkan kemampuan dan membentuk watak serta peradaban bangsa yang bermartabat dalam rangka mencerdaskan kehidupan bangsa, bertujuan untuk berkembangnya potensi peserta didik agar menjadi manusia yang beriman dan bertakwa kepada Tuhan Yang Maha Esa, berakhlak mulia, sehat, berilmu, cakap, kreatif, mandiri, dan menjadi warga negara yang

${ }^{1}$ Nana Syaodih Sukmadinata, Pengembangan KurikulumTeori dan Praktek (Bandung: Remaja Rosdakarya, 2006), hlm. 5. 
demokratis serta bertanggung jawab dalam segala urusan yang menjadi tanggung jawabnya.

\section{KTSP (Kurikulum Tingkat Satuan Pendidikan) Pengertian KTSP}

Kurikulum Tingkat Satuan Pendidikan (KTSP) adalah kurikulum yang disusun dan dilaksanakan di masing-masing satuan pendidikan. ${ }^{2}$ Kurikulum Tingkat Satuan Pendidikan (KTSP) adalah kurikulum operasional yang disusun dan dilaksanakan di masing-masing satuan pendidikan dengan memerhatikan dan berdasarkan standar kompetensi serta kompetensi dasar yang dikembangkan oleh Badan Standar Nasional Pendidikan (BSNP).

Kurikulum Tingkat Satuan Pendidikan (KTSP) mengandung makna bahwa kurikulum dikembangkan oleh masing-masing satuan pendidikan dengan tujuan agar satuan pendidikan yang bersangkutan dapat mengembangkan kekhasan potensi sumber daya manusia dan daerah di sekitarnya. Hal ini merupakan implikasi dari perubahan kebijakan dari sentralisasi ke desentralisasi di bidang pendidikan. Perubahan ini menuntut adanya perubahan paradigma dalam membina satuan pendidikan. Pembinaan yang selama ini dilakukan secara terpusat dialihkan menjadi pendampingan terhadap masing-masing satuan pendidikan.

Menurut PP Nomor 19 Tahun 2006 tentang Standar Nasional Pendidikan Pasal (1) Ayat (15) dikemukakan bahwa: "Kurikulum tingkat satuan pendidikan adalah kurikulum operasional yang disusun oleh dan dilaksanakan di masing-masing satuan pendidikan". ${ }^{3}$ Penyusunan KTSP dilakukan oleh satuan pendidikan denganmemperhatikan dan berdasarkan standar kompetensi serta kompetensi dasar yang dikembangkan oleh Badan Standar Nasional Pendidikan (BSNP).

${ }^{2}$ Khaeruddin, dkk., Kurikulum Tingkat Satuan Pendidikan (KTSP) Konsep dan Implementasinya di Madrasah (Jogjakarta: Pilar Media, 2007), hlm. 79.

${ }^{3}$ Tim Pustaka Yustisia, Panduan Lengkap KTSP (Kurikulum Tingkat Satuan Pendidikan) (Yogyakarta: PustakaYustisia, 2007), hlm. 3. 
Otonomi penyelenggaraan pendidikan tersebut kemudian berimplikasi pada perubahan sistem manajemen pendidikan dari pola sentralisasi ke desentralisasi dalam pengelolaan pendidikan. Manajemen yang dikembangkan lebih mengarah pada manajemen berbasis sekolah atau madrasah (school based management) atau manajemen peningkatan mutu berbasis sekolah atau madrasah. ${ }^{4}$

Secara teknis, pelaksanaan pengembangan KTSP dapat dikelompokkan dalam tiga tahapan, diawali dengan tahap pertama, yaitu: Analisis Konteks. Adapun hal yang dilakukan dalam tahapan pertama ini adalah menganalisa potensi dan kekuatan maupun kelemahan sekolah, menganalisis peluang dan tantangan di masyarakat dan yang ada di lingkungan sekitar, kemudian mengidentifikasi Standar Isi dan Standar Kompetensi Lulusan sebagai acuan dalam penyusunan KTSP. Kedua, Mekanisme Penyusunan. yang perlu diperhatikan dalam tahap ini adalah bagian Tim Penyusun dan Kegiatan.

Tim Penyusun maksudnya yaitu kurikulum dikembangkan berdasarkan relevansi oleh setiap kelompok atau satuan pendidikan dan komite Sekolah/Madrasah dibawah koordinasi dan supervisi dinas pendidikan atau Kantor Departemen Agama Kabupaten/Kota untuk pendidikan Dasar dan Menengah. Kegiatan tahap penyusunan secara umumnya meliputi penyiapan dan penyusunan draf, review, dan revisi, serta finalisasi. Ketiga, dokumen masing-masing satuan pendidikan dinyatakan berlaku oleh kepala sekolah serta diketahui oleh komite sekolah dan dinas Kabupaten/Kota yang bertanggung jawab di bidang pendidikan. ${ }^{5}$

\section{Karakteristik KTSP}

Karakteristik Kurikulum Tingkat Satuan Pendidikan (KTSP) yaitu: ${ }^{6}$

${ }^{4}$ Muhaimin, Suti'ah dan Sugeng Listyo Prabowo, Pengembangan Model Kurikulum Tingkat Satuan Pendidikan (KTSP) pada Sekolah dan Madrasah (Jakarta: Raja Grafindo Persada, 2008), hlm. 2.

${ }^{5}$ Masnur Muslich, KTSP Dasar Pemahaman dan Pengembangan, (Jakarta: Pustaka Setia, 2008), hlm. 26-28.

${ }^{6}$ Tim Pustaka Yustisia, Op. Cit., hlm. 29. 
1. Pemberian otonomi yang luas kepada sekolah sebagai satuan pendidikan.

2. Partisipasi masyarakat dan orang tua yang tertinggi.

3. Kepemimpinan yang demokratis dan profesional.

4. Dan tim-kerja yang kompak dan transparan

Melalui, sekolah dan satuan pendidikan perlu mengembangkan lembaga yang diberi kewenangan dan tanggung jawab secara luas, mandiri dan maju serta berkembang berdasarkan strategi kebijakan manajemen pendidikan yang diterapkan pemerintah.

\section{Landasan KTSP}

Penyelenggaraan Kurikulum Tingkat Satuan Pendidikan (KTSP) yang saat ini diterapkan di Indonesia dilandasi oleh kebijakan perundangundangan sebagai berikut:

1. Undang-Undang Republik Indonesia Nomor 20 Tahun 2003 tentang Sistem Pendidikan Nasional,

2. Peraturan Pemerintah Republik Indonesia Nomor 19 Tahun 2005 tentang Standar Nasional Pendidikan

3. Peraturan Menteri Pendidikan Nasional Republik Indonesia Nomor 22 Tahun 2006 tentang Standar Isi untuk Satuan Pendidikan Dasar dan Menengah. Standar isi ini mencakup lingkup materi dan tingkat kompetensi untuk mencapai kompetensi lulusan pada jenjang dan jenis pendidikan tertentu. Termasuk dalam standar isi adalah: kerangka dasar dan struktur kurikulum, Standar Kompetensi (SK) dan Kompetensi Dasar (KD) setiap mata pelajaran pada setiap semester dari setiap jenis dan jenjang pendidikan dasar dan menengah.

4. Peraturan Menteri Pendidikan Nasional Republik Indonesia Nomor 23 Tahun 2006 tentang Standar Kompetensi Lulusan untuk Satuan Pendidikan Dasar dan Menengah. Standar Kompetensi Lulusan merupakan kualifikasi kemampuan lulusan yang mencakup sikap, pengetahuan dan keterampilan.

5. Peraturan Menteri Pendidikan Nasional Republik Indonesia Nomor 24 Tahun 2006 tentang Pelaksanaan Peraturan Menteri Pendidikan Nasional Nomor 22 Tahun 2006 tentang Standar Isi untuk Satuan 
Rosiddin Harahap

Pendidikan Dasar dan Menengah dan Peraturan Menteri Pendidikan Nasional Nomor 23 Tahun 2006 tentang Standar Kompetensi Lulusan untuk Satuan Pendidikan Dasar dan Menengah. ${ }^{7}$

6. Peraturan Menteri Agama Republik Indonesia nomor 2 tentang Standart Kompetensi Lulusan dan Standart Isi Pendidikan Agama Islam dan bahasa Arab di Madrasah.

\section{Tujuan KTSP}

Secara umum tujuan diterapkannya KTSP adalah untuk memandirikan dan memberdayakan satuan pendidikan melalui pemberian kewenangan (otonomi) kepada lembaga pendidikan. Secara khusus tujuan diterapkannya KTSP adalah: ${ }^{2}$

1. Untuk meningkatkan mutu pendidikan melalui kemandirian dan inisiatif sekolah dalam mengembangkan kurikulum, mengelola, dan memberdayakan sumber daya yang tersedia.

2. Meningkatkan kepedulian warga sekolah dan masyarakat dalam pengembangan kurikulum melalui pengambilan keputusan bersama. Sebagai kurikulum operasional, KTSP menuntut keterlibatan masyarakat secara penuh, sebab tanggung jawab pengembangan kurikulum tidak lagi berada di pemerintah, akan tetapi disekolah, sedangkan sekolah akan berkembang manakala ada keterlibatan masyarakat.

3. Meningkatkan kompetisi yang sehat antar satuan pendidikan tentang kualitas pendidikan yang akan dicapai. Melalui KTSP diharapkan setiap sekolah atau satuan pendidikan akan berlomba dalam menyusun program kurikulum sekaligus berlomba dalam mengimplementasikannya. ${ }^{9}$

\section{Prinsip-Prinsip KTSP}

7http://dikmenum.go.id, Salinan Lampiran Permendikbud No. 67 Tahun 2013, Diakses pada tanggal 01 Oktober 2016

${ }^{8}$ Muhaimin, dkk, Pengembangan Model KTSP pada Sekolah dan Madrasah, Jakarta: Raja Grafindo Persada, 2007), hlm. 21-23.

${ }^{9}$ http://nisabumkhairun.blogspot.co.id/2014/03/makalah-ktsp.html diakses pada tanggal 01 Oktober 2016. 
Prinsip-prinsip dalam pengembangan kurikulum tingkat satuan yaitu sebagai berikut:

1. Berpusat pada potensi, perkembangan, kebutuhan dan kepentingan peserta didik dan lingkungannya. KTSP memiliki prinsip bahwa peserta didik memiliki posisi sentral untuk mengembangkan kompetensinya agar menjadi manusia yang beriman dan bertakwa kepada Tuhan Yang Maha Esa, berakhlak mulia, sehat, berilmu, cakap, kreatif, mandiri dan menjadi warga negara yang demokratis serta bertanggung jawab. Memiliki posisi sentral berarti kegiatan pembelajaran berpusat pada peserta didik (student centered). Di samping itu juga Pengembangan KTSP perlu memerhatikan potensi dan kebutuhan lingkungan di mana siswa tinggal, karena pendidikan pada hakikatnya adalah upaya mempersiapkan anak didik agar mampu hidup dan mengembangkan lingkungannya.

2. Beragam dan terpadu. Penerapan kurikulum memerhatikan keragaman karakteristik peserta didik, kondisi daerah, jenjang dan jenis pendidikan, serta menghargai dan tidak diskriminatif terhadap perbedaan agama, suku, budaya, adat istiadat, status sosial, ekonomi, dan gender. Kurikulum meliputi substansi komponen muatan wajib kurikulum, muatan lokal, dan pengembangan diri secara terpadu, serta disusun dalam keterkaitan dan kesinambungan yang bermakna.

3. Tanggap terhadap perkembangan ilmu pengetahuan, teknologi dan seni. Kurikulum diterapkan atas dasar kesadaran bahwa ilmu pengetahuan, teknologi, dan seni berkembang secara dinamis. Oleh karena itu semangat dan isi kurikulum memberikan pengalaman belajar peserta didik untuk mengikuti dan memanfaatkan perkembangan ilmu pengetahuan, teknologi, dan seni.

4. Relavan dengan kebutuhan kehidupan. Pengembangan kurikulum dilakukan dengan melibatkan pemangku kepentingan (stakeholders) untuk menjamin relevansi pendidikan dengan kebutuhan kehidupan, termasuk di dalamnya kehidupan kemasyarakatan, dunia usaha dan dunia kerja. Oleh karena itu, pengembangan keterampilan pribadi, 


\section{Rosiddin Harahap}

keterampilan berpikir, keterampilan sosial, keterampilan akademik, dan keterampilan vokasional merupakan keniscayaan.

5. Menyeluruh dan berkesinambungan. Substansi kurikulum mencakup keseluruhan dimensi kompetensi. bidang kajian keilmuan dan mata pelajaran yang direncanakan dan disajikan secara berkesinambungan antar semua jenjang pendidikan.

6. Belajar sepanjang hayat. Kurikulum diarahkan kepada proses pengembangan, pembudayaan, dan pemberdayaan peserta didik yang berlangsung sepanjang hayat. Kurikulum mencerminkan keterkaitan antara unsur-unsur pendidikan formal, nonformal, dan informal dengan memerhatikan kondisi dan tuntutan lingkungan yang selalu berkembang serta arah pengembangan manusia seutuhnya.

7. Seimbang antara kepentingan nasional dan kepentingan daerah. Kurikulum diterapkankan dengan memerhatikan kepentingan nasional dan kepentingan daerah untuk membangun kehidupan bermasyarakat, berbangsa, dan bernegara. Kepentingan nasional dan kepentingan daerah harus saling mengisi dan memberdayakan sejalan dengan moto Bhineka Tunggal Ika dalam kerangka Negara Kesatuan Republik Indonesia (NKRI).

Acuan operasional penyusun kurikulum tingkat satuan pendidikan PAl adalah sebagai berikut:

1. Peningkatan iman dan takwa

2. Peningkatan akhlak mulia.

3. Peningkatan potensi, kecerdasan, dan minat peserta didik.

4. Keragaman potensi dan kerakter daerah dan lingkungan.

5. Tuntutan pembangunan daerah dan nasional.

6. Tuntutan dunia kerja.

7. Perkembangan ilmu pengetahuan dan teknologi dan seni.

8. Agama.

9. Dinamika perkembangan global. ${ }^{10}$

${ }^{10}$ Wina Sanjaya, Stategi Pembelajaran (Jakarta: Kencana Prenada Media, 2008), hlm. 135-136; Lihat juga Masnur Muslich, KTSP: Pembelajaran Berbasis Kompetensi dan Kontekstual, Cet. 1 (Jakarta: Bumi Aksara, 2007), hlm. 18. 
Dengan demikian, penerapan kurikulum tingkat satuan pendidikan di Sekolah adalah untuk meningkatkan relevansi pendidikan dimaksudkan untuk menghasilkan lulusan yang sesuai dengan tuntutan kebutuhan berbasis kopetensi.

\section{Struktur Kurikulum Madrasah}

Berdasarkan Peraturan Menteri Agama Nomor 2 tahun 2008 Struktur kurikulum madrasah dijelaskan dari peraturan yang ada yang telah dikeluarkan oleh Peraturan Menteri Pendidikan tentang KTSP sangat berbeda dari segi strukturnya untuk mata pelajaran Pendidikan Agama Islam yang terdiri dari Qur'an Hadits, Aqidah Akhlak, Piqih, SKI dan bahasa Arab untuk tingkat MI dan MTs, terdiri dari 10 jam pelajaran per minggu.

\section{Kurikulum 2013}

\section{Pengertian Kurikulum 2013}

Kurikulum 2013 adalah kurikulum berbasis kompetensi yang dirancang untuk mengantisipasi kebutuhan kompetensi abad ke-21. Kurikulum 2013 mempunyai tujuan untuk mendorong peserta didik atau siswa, mampu lebih baik melakukan observasi, bertanya, bernalar, dan mengkomunikasikan (mempresentasikan) apa yang mereka peroleh atau mereka ketahui setelah menerima materi pelajaran. Pelaksanaan penyusunan kurikulum 2013 adalah bagian dari melanjutkan pengembangan Kurikulum Berbasis Kompetensi (KBK) yang telah dirintis pada tahun 2004.

Implementasi kurikulum 2013 berbasis kompetensi dan karakter harus melibatkan semua komponen (stakeholders), termasuk komponenkomponen sistem pendidikan itu sendiri. Pendidikan karakter dalam kurikulum 2013 diharapkan dapat meningkatkan mutu proses dan hasil pendidikan yang mengarah pada pembentukan budi pekerti dan akhlak mulia peserta didik secara utuh dan seimbang, sesuai dengan standart kompetensi pada setiap jenjang pendidikan.

Karakter adalah gambaran tingkah laku yang dimiliki oleh seseorang yang mencerminkan nilai-nilai kehidupan dan melekat pada diri seseorang. Orang yang berkarakter memeilki berbagai dimensi misalnya, dimensi sosial, 
fisik, emosi, dan akademik. Jika disejajarkan dengan ranah Bloom, berarti manusia berkarakter memiliki ranah kognisi, afeksi, dan psikomotorik yang baik, ditambah dengan emosi, spiritual, ketahanan menghadapi masalah dan sosial. ${ }^{11}$

Dengan demikian, perpaduan dua basis antara kompetensi dan karakter dalam kurikulum ini diharapkan siswa dapat meningtkan dan menggunakan pengetahuannya, mengkaji, dan menginternalisasi serta mempersonalisasi nilai-nilai karakter dan akhlak mulia sehingga terwujud dalam kehidupan sehari-hari.

Penddidikan karakter dalam kurikulum 2013 bukan hanya tanggung jawab sekolah semata, tetapi merupakan tanggung jawab semua pihak. Untuk mengefektifkan program pendidikan karakter dan meningkatkan kompetensi dalam kurikulum 2013 diperlukan kordinasi, komunikasi dan jalinan kerja antara sekolah, orangtua, dan pemerintah dalam semua sisi.

\section{Landasan Kurikulum 2013}

Kurikulum 2013 dikembangkan dengan landasan filosofis yang memberikan dasar bagi pengembangan seluruh potensi peserta didik menjadi manusia Indonesia berkualitas yang tercantum dalam tujuan pendidikan nasional.

Kurikulum 2013 dikembangkan atas teori "pendidikan berdasarkan standar" (standard-based education), dan teori kurikulum berbasis kompetensi (competency-based curriculum). Landasan Kurikulum 2013 adalah: ${ }^{12}$

1. Undang-Undang Dasar Negara Republik Indonesia Tahun 1945;

2. Undang-undang RI Nomor 20 Tahun 2003 tentang Sistem Pendidikan Nasional;

3. Undang-undang RI Nomor 17 Tahun 2005 tentang Rencana Pembangunan Jangka Panjang Nasional, beserta segala ketentuan yang dituangkan Rencana Pembangunan Jangka Menengah Nasional; dan

\footnotetext{
${ }^{11}$ Anisahlzzaty, InovasidalamBidangKurikulum 2013 danmutuPendidikan.,dalam Http//Izzatyalmuhyi.blogspot.com (on line) Diaksespadatanggal01 Oktober 2016

${ }^{12}$ /bid.
} 
4. Peraturan Pemerintah RI Nomor 19 Tahun 2005 tentang Standar Nasional Pendidikan sebagaimana telah diubah dengan Peraturan Pemerintah Nomor 32 Tahun 2013 tentang Perubahan Atas Peraturan Pemerintah Nomor 19 Tahun 2005 tentang Standar Nasional Pendidikan.

5. Keputusan Menteri Agama Republik Indonesia nomor 165 tentang Standart Kompetensi Lulusan dan Standart Isi Pendidikan Agama Islam dan bahasa Arab di Madrasah.

\section{Karakteristik Kurikulum 2013}

Sedangkan karakteristik Kurikulum 2013 mempersiapkan peserta didik dalam menghadapi tantangan-tantangan di masa depan melalui pengetahuan, keterampilan, sikap dan keahlian untuk beradaptasi serta bisa bertahan hidup dalam lingkungan yang senantiasa berubah. Menteri Pendidikan dan Kebudayaan Muhammad Nuh menegaskan bahwa perubahan dan pengembangan kurikulum 2013 merupakan persoalan yang genting dan penting. Alasan perubahan kurikulum dari KTSP menjadi kurikulum 2013 adalah kurikulum harus lebih berbasis pada penguatan penalaran, bukan lagi hafalan semata.

Struktur kurikulumnya berdasarkan pada Keputusan Menteri Agama Republik Indonesia nomor 165 tentang Standar Kompetensi Lulusan dan Standart Isi Pendidikan Agama Islam dan bahasa Arab di Madrasah

\section{Sistem Evaluasi dalam Kurikulum 2013}

Kesalahan fatal dalam implementasi Kurikulum Berbasis Kompetensi (KBK) dan Kurikulum Tingkat Satuan Pendidikan (KTSP) selama ini menurut saya adalah kemunculan kebijakan yang sejatinya tidak konsisten dengan kurikulum-kurikulum tersebut. Kebijaksanaan yang dimaksud adalah pelaksanaan ujian nasional dengan standar kelulusannya. Dimana siswa dikatakan berhasil jika ia telah mampu menembus jaring ujian nasional. Sebuah sekolah dikatakan bermutu apabila kelulusan siswanya 100\% dan banyak siswanya yang mendapatkan nilai 10. Bahkan untuk tujuan itu, kecurangan sistematis selalu terjadi. Penanaman nilai moral seolah tak diperhatikan. 
Oleh karena itu, jika nantinya Kurikulun 2013 diterapkan dan ditujukan agar guru memperoleh ruang yang lebih leluasa untuk mengembangkan potensi siswa secara seimbang dalam tiga aspek, yaitu aspek kognitif, psikomotorik dan afektif. Kurikulum ini harus dikawal dengan kebijakan yang sinergis. Dan akhirnya siswa dapat belajar dengan semangat, antusias, tidak bosan dan mampu menyerap nilai-nilai moral yang terkandung secara tersitat dalam setiap materi. ${ }^{13}$

\section{Prinsip-prinsip K-13}

Setiap kurikulum pastinya mempunyai prinsip. Karena prinsip merupakan landasan atau acuan untuk mengembangkan kurikulum. Seperti halnya kurikulum 2013 yang baru dirintis ini mempunyai beberapa prinsip yaitu: Kurikulum satuan pendidikan atau jenjang pendidikan bukan merupakan daftar mata pelajaran. Atas dasar prinsip tersebut maka kurikulum sebagai rencana adalah rancangan untuk konten pendidikan yang harus dimiliki oleh seluruh peserta didik setelah menyelesaikan pendidikannya di satu satuan atau jenjang pendidikan tertentu. Kurikulum sebagai proses adalah totalitas pengalaman belajar peserta didik di satu satuan atau jenjang pendidikan untuk menguasai konten pendidikan yang dirancang dalam rencana. Hasil belajar adalah perilaku peserta didik secara keseluruhan dalam menerapkan perolehannya di masyarakat.

1. Standar kompetensi lulusan ditetapkan untuk satu satuan pendidikan, jenjang pendidikan, dan program pendidikan. Sesuai dengan kebijakan Pemerintah mengenai Wajib Belajar 12 Tahun maka Standar Kompetensi Lulusan yang menjadi dasar pengembangan kurikulum adalah kemampuan yang harus dimiliki peserta didik setelah mengikuti proses pendidikan selama 12 tahun. Selain itu sesuai dengan fungsi dan tujuan jenjang pendidikan dasar dan pendidikan menengah serta fungsi dan tujuan dari masing-masing satuan pendidikan pada setiap jenjang pendidikan maka pengembangan kurikulum didasarkan pula atas

${ }^{13}$ E. Mulyasa, Pengembangan dan Implemtasi Kurikulum 2013 (Bandung: Remaja Rosdakarya) hlm.164. 
Standar Kompetensi Lulusan pendidikan dasar dan pendidikan menengah serta Standar Kompetensi satuan pendidikan.

2. Kurikulum didasarkan pada prinsip bahwa setiap sikap, keterampilan dan pengetahuan yang dirumuskan dalam kurikulum berbentuk Kemampuan Dasar dapat dipelajari dan dikuasai setiap peserta didik (mastery learning).

3. Kurikulum berpusat pada potensi, perkembangan, kebutuhan, dan kepentingan peserta didik serta lingkungannya.

4. Kurikulum harus tanggap terhadap perkembangan ilmu pengetahuan, budaya, teknologi, dan seni. Kurikulum dikembangkan atas dasar kesadaran bahwa ilmu pengetahuan, budaya, teknologi, dan seni berkembang secara dinamis. Oleh karena itu konten kurikulum harus selalu mengikuti perkembangan ilmu pengetahuan, budaya, teknologi, dan seni; membangun rasa ingin tahu dan kemampuan bagi peserta didik untuk mengikuti dan memanfaatkan secara tepat hasil-hasil ilmu pengetahuan, teknologi, dan seni.

5. Kurikulum dikembangkan dengan memperhatikan kepentingan nasional dan kepentingan daerah untuk membangun kehidupan bermasyarakat, berbangsa dan bernegara. Kepentingan nasional dikembangkan melalui penentuan struktur kurikulum, Standar Kemampuan/SK dan Kemampuan Dasar/KD serta silabus. ${ }^{14}$

\section{Perbandingan KTSP dan Kurikulum 2013}

Berikut ini Persamaan dan Perbedaan Kurikulum KTSP dengan Kurikulum 2013 di Tingkat Madrasah Aliyah:

a. Perbedaan

\section{Tabel 1}

${ }^{14}$ Tinjauan Kurikulum 2013 dan Buku Ajar http://nasional.news.co. id. Diakses pada tanggal 01 Oktober 2016. 
Perbedaan Kurikulum KTSP dan K-13

\begin{tabular}{|c|c|c|}
\hline No & Kurikulum 2013 & KTSP \\
\hline 1 & $\begin{array}{l}\text { SKL (Standar Kompetensi Lulusan) } \\
\text { ditentukan terlebih dahulu, melalui } \\
\text { Permendikbud No } 54 \text { Tahun } 2013 . \\
\text { Setelah itu baru ditentukan Standar } \\
\text { Isi, yang bebentuk Kerangka Dasar } \\
\text { Kurikulum, yang dituangkan dalam } \\
\text { Permendikbud No 67, 68, 69, dan } \\
70 \text { Tahun } 2013\end{array}$ & $\begin{array}{l}\text { Standar Isi ditentukan terlebih } \\
\text { dahulu melaui Permendiknas } \\
\text { No } 22 \text { Tahun 2006. Setelah itu } \\
\text { ditentukan SKL (Standar } \\
\text { Kompetensi Lulusan) melalui } \\
\text { Permendiknas No } 23 \text { Tahun } \\
2006\end{array}$ \\
\hline 2 & $\begin{array}{l}\text { Aspek kompetensi lulusan ada } \\
\text { keseimbangan soft skills dan hard } \\
\text { skills yang meliputi aspek } \\
\text { kompetensi sikap, keterampilan, } \\
\text { dan pengetahuan }\end{array}$ & $\begin{array}{l}\text { Lebih menekankan pada aspek } \\
\text { pengetahuan }\end{array}$ \\
\hline 3 & $\begin{array}{l}\text { di jenjang SD Tematik Terpadu } \\
\text { untuk kelas I-VI }\end{array}$ & $\begin{array}{l}\text { di jenjang SD Tematik Terpadu } \\
\text { untuk kelas I-III }\end{array}$ \\
\hline 4 & $\begin{array}{l}\text { Jumlah jam pelajaran per minggu } \\
\text { lebih banyak dan jumlah mata } \\
\text { pelajaran lebih sedikit dibanding } \\
\text { KTSP }\end{array}$ & $\begin{array}{l}\text { Jumlah jam pelajaran lebih } \\
\text { sedikit dan jumlah mata } \\
\text { pelajaran lebih banyak } \\
\text { dibanding Kurikulum } 2013\end{array}$ \\
\hline 5 & $\begin{array}{l}\text { Proses pembelajaran setiap tema di } \\
\text { jenjang SD dan semua mata } \\
\text { pelajaran di jenjang SMP/SMA/ } \\
\text { SMK dilakukan dengan pendekatan } \\
\text { ilmiah yaitu standar proses dalam } \\
\text { pembelajaran terdiri dari } \\
\text { Mengamati, Menanya, Mengolah, } \\
\begin{array}{l}\text { Menyajikan, Menyimpulkan, dan } \\
\text { Mencipta. }\end{array}\end{array}$ & $\begin{array}{lrr}\text { Standar } & \text { proses } & \text { dalam } \\
\text { pembelajaran } & \text { terdiri } & \text { dari } \\
\text { Eksplorasi, } & \text { Elaborasi, } & \text { dan } \\
\text { Konfirmasi } & & \end{array}$ \\
\hline No & Kurikulum 2013 & KTSP \\
\hline 6 & (Teknologi Informasi & i mats \\
\hline
\end{tabular}




\begin{tabular}{|c|c|c|}
\hline & $\begin{array}{l}\text { Komunikasi) bukan sebagai mata } \\
\text { pelajaran, melainkan sebagai media } \\
\text { pembelajaran }\end{array}$ & \\
\hline 7 & $\begin{array}{l}\text { Standar penilaian menggunakan } \\
\text { penilaian otentik, yaitu mengukur } \\
\text { semua kompetensi sikap, } \\
\text { keterampilan, dan pengetahuan } \\
\text { berdasarkan proses dan hasil. }\end{array}$ & $\begin{array}{l}\text { Penilaiannya lebih dominan } \\
\text { pada aspek pengetahuan }\end{array}$ \\
\hline 8 & Pramuka menjadi ekstrakuler wajib & $\begin{array}{l}\text { Pramuka bukan } \\
\text { kurikuler wajib }\end{array}$ \\
\hline 9 & $\begin{array}{l}\text { Pemintan (Penjurusan) mulai kelas } \\
\text { X untuk jenjang SMA/MA }\end{array}$ & Penjurusan mulai kelas XI \\
\hline 10 & $\begin{array}{l}\text { BK lebih menekankan mengem- } \\
\text { bangkan potensi siswa }\end{array}$ & $\begin{array}{l}\text { BK lebih pada menyelesaikan } \\
\text { masalah siswa }\end{array}$ \\
\hline
\end{tabular}

Tabel 2

Perbedaan KTSP dan K-13

\begin{tabular}{|c|l|l|}
\hline \multicolumn{1}{|c|}{ Aspek } & \multicolumn{1}{|c|}{ KTSP } & \multicolumn{1}{c|}{ K-13 } \\
\hline Peran Guru & $\begin{array}{l}\text { Guru } \\
\text { fasilitator } \\
\text { mengkondisikan } \\
\text { siswanya } \\
\text { Berpusat pada siswa }\end{array}$ & $\begin{array}{l}\text { Guru meningatkan } \\
\text { efektifitas pembelajaran }\end{array}$ \\
\hline Sumber Belajar & $\begin{array}{l}\text { Berbagai } \\
\text { Sumberbelajar }\end{array}$ & $\begin{array}{l}\text { Buku ditulis mengacu } \\
\text { pada konsep kurikulum } \\
\text { (KI, KD, Silabus) }\end{array}$ \\
\hline Pembelajaran & $\begin{array}{l}\text { Kegiatan pembela- } \\
\text { jaran lebih bervariasi, } \\
\text { menyenangkan dan } \\
\text { dinamis }\end{array}$ & $\begin{array}{l}\text { Setiap mengajar ada dua } \\
\text { jenis buku yaitu buku } \\
\text { siswa dan buku guru }\end{array}$ \\
\hline
\end{tabular}

\begin{tabular}{l|l|l} 
Aspek & KTSP & K-13 \\
\hline
\end{tabular}




\begin{tabular}{|c|c|c|}
\hline $\begin{array}{l}\text { Persiapan } \\
\text { Mengajar }\end{array}$ & $\begin{array}{l}\text { Guru dituntut agar } \\
\text { lebih kreatif }\end{array}$ & $\begin{array}{l}\text { Alokasi waktu untuk } \\
\text { persiapan silabus dan } \\
\text { review buku ajar }\end{array}$ \\
\hline Penilaian & $\begin{array}{l}\text { Evaluasi berbasis kelas } \\
\text { yang menekankan } \\
\text { pada proses dan hasil } \\
\text { belajar }\end{array}$ & $\begin{array}{l}\text { - Menekankan } \\
\text { kompetensi sikap } \\
\text { (spiritual dan sosial) } \\
\text { · Menggunakan } \\
\text { portopolio pembelajaran } \\
\text { siswa } \\
\text { · Mengukur tingkat } \\
\text { berfikir siswa mulai dari } \\
\text { yang rendah sampai } \\
\text { yang tinggi } \\
\text { · Mengukur pada proses } \\
\text { kerja bukan hasil kerja }\end{array}$ \\
\hline
\end{tabular}

Itulah beberpa perbedaan Kurikulum 2013 dan KTSP. Walaupun kelihatannya terdapat perbedaan yang sangat jauh antara Kurikulum 2013 dan KTSP, namun sebenarnya terdapat kesamaan ESENSI Kurikulum 2013 dan KTSP. Misal pendekatan ilmiah (Saintific Approach) yang pada hakekatnya adalah pembelajaran berpusat pada siswa. Siswa mencari pengetahuan bukan menerima pengetahuan. Pendekatan ini mempunyai esensi yang sama dengan Pendekatan Keterampilan Proses (PKP). Masalah pendekatan sebenarnya bukan masalah kurikulum, tetapi masalah implementasi yang tidak jalan di kelas. Bisa jadi pendekatan ilmiah yang diperkenalkan di Kurikulum 2013 akan bernasib sama dengan pendekatanpendekatan kurikulum terdahulu bila guru tidak paham dan tidak bisa menerapkannya dalam pembelajaran di kelas.

\section{b. Persamaan}

Kurikulum 2006 (KTSP) dan Kurikulum 2013 sama-sama menampilkan teks sebagai butir-butir KD.

1. Untuk struktur kurikulumnya baik pada KTSP atau pada 2013 sama-sama dibuat atau dirancang oleh pemerintah tepatnya oleh Depdiknas. 
2. Beberapa mata pelajaran masih ada yang sama seperti KTSP.

3. Terdapat kesamaan esensi kurikulum, misalnya pada pendekatan ilmiah yang pada hakekatnya berpusat pada siswa. Dimana siswa yang mencari pengetahuan bukan menerima pengetahuan.

\section{Penutup}

KTSP adalah Kurikulum Tingkat Satuan Pendidikan (KTSP) mengandung makna bahwa kurikulum dikembangkan oleh masing-masing satuan pendidikan dengan tujuan agar satuan pendidikan yang bersangkutan dapat mengembangkan kekhasan potensi sumber daya manusia dan daerah di sekitarnya. K-13 adalah Kurikulum 2013 adalah kurikulum berbasis kompetensi yang dirancang untuk mengantisipasi kebutuhan kompetensi abad ke-21.

KTSP adalah suatu ide tentang pengembangan yang diletakkan pada posisi yang paling dekat dengan pembelajaran, yakni sekolah dan satuan pendidikan. KTSP merupakan wujud dari reformasi pendidikan yang memberikan otonomi kepada sekolah dan satuan pendidikan untuk mengembangkan kurikulum sesuai dengan potensi, tuntutan dan kebutuhan masing-masing.

Diterapkannya KTSP adalah untuk memandirikan dan memberdayakan satuan pendidikan melalui pemberian kewenangan (otonomi) kepada lembaga pendidikan dan mendorong sekolah untuk melakukan pengambilan keputusan dalam pengembangan kurikulum.

Selanjutnya pada Kurikulum 2013 mempunyai tujuan untuk mendorong peserta didik atau siswa, mampu lebih baik melakukan observasi, bertanya, bernalar, dan mengkomunikasikan (mempresentasikan) apa yang mereka peroleh atau mereka ketahui setelah menerima materi pelajaran.

\section{Daftar Pustaka}


Rosiddin Harahap

E. Mulyasa, Pengembangan dan Impelemtasi Kurikulum 2013, Bandung: Remaja Rosdakarya, 2006.

Masnur Muslich, KTSP Dasar Pemahaman dan Pengembangan, Jakarta: Pustaka Setia, 2008.

Masnur Muslich, KTSP: Pembelajaran Berbasis Kompetensi dan Kontekstual, Cet. 1, Jakarta: Bumi Aksara, 2007.

Muhaimin, Suti'ah dan Sugeng Listyo Prabowo, Pengembangan Model Kurikulum Tingkat Satuan Pendidikan (KTSP) pada Sekolah dan Madrasah, Jakarta: Raja Grafindo Persada, 2008.

dkk, Pengembangan Model KTSP pada Sekolah dan Madrasah, Jakarta: Raja Grafindo Persada, 2007.

Nana Syaodih Sukmadinata, Pengembangan Kurikulum Teori dan Praktek, Bandung: Remaja Rosdakarya, 2006.

Khaeruddin, dkk., Kurikulum Tingkat Satuan Pendidikan (KTSP) Konsep dan Implementasinya di Madrasah, Jogjakarta: Pilar Media, 2007.

http://dikmenum.go.id, SalinanLampiranPermendikbud No. 67 Tahun 2013. Diakses pada tanggal 01 Oktober 2016.

Tinjauan Kurikulum 2013 dan Buku Ajar http://nasional.news.co. id. Diakses pada tanggal 01 Oktober 2016.

Tim Pustaka Yustisia, Panduan Lengkap KTSP (Kurikulum Tingkat Satuan Pendidikan), Yogyakarta: Pustaka Yustisia, 2007.

Wina Sanjaya, Stategi Pembelajaran, Jakarta: Kencana Prenada Media, 2008. 